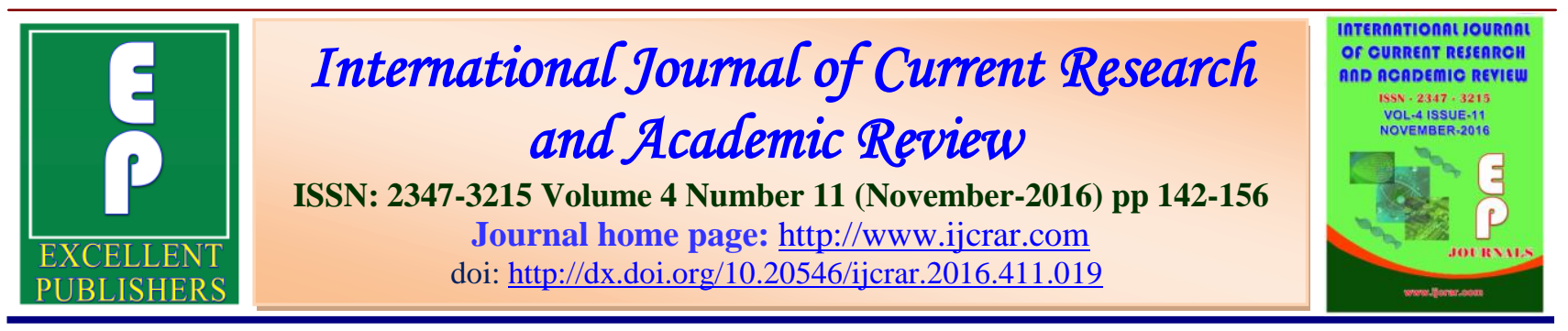

\title{
Extent, Diversity and Potential of Extant Textile Enterprises in India: A Cross State Analysis of the Informal/Unincorporated Economy
}

\author{
Meenakshi Sinha Swami ${ }^{1 *}$ and Stanzin Padma ${ }^{2}$ \\ ${ }^{1}$ Assistant Professor, Department of Economics, Mata Sundari College for Women, University \\ of Delhi, New Delhi, India \\ ${ }^{2}$ Research Scholar, Centre for the Study of Regional Development, School of School of Social \\ Sciences, CSRD-JNU, New Delhi, India \\ *Corresponding author
}

\begin{tabular}{l|l} 
KEYWORDS & A B S T R A C T
\end{tabular}

Diversity,

Textile Enterprises,

Informal/

Unincorporated

Economy

Textile enterprises are spread across the length and breadth of India and they are a major employer in the Indian manufacturing sector. The paper examines the importance of the textile enterprises in India based on statistics and the initiatives undertaken by the government. This research paper explores the potential of the textile industry and extensive spread of textile enterprises among various states based on a cross state analysis of the types of activities undertaken by the textile manufacturing sector and the concentration of the different types of manufacturing among states based on National Sample Survey conducted by the Ministry of Statistics and Planning, Government of India. The paper also highlights the growth drivers for the textile industry which can make the industry more receptive to the changing demand scenario to boost growth prospects. The textile sector is unevenly spread across the country and most of the states are dependent on the traditional knowledge of the weavers and the traditional crafts of the region in particular for traditional enterprises in the informal economy.. The government has been working hard to bolster the traditional crafts but the problems at the grassroots level are often overlooked.

\section{Introduction}

Indian textiles industry pervades the social and economic life of the country. The diversity of enterprises found in India is due to the variety of weaving patronized by the rulers once.
The textile sector in India is one of the mainstays of the national economy. The Indian textiles industry, currently estimated at around US $\$ 108$ billion, is expected to reach US \$ 141 billion by 2021. The 
industry is the second largest employer after agriculture, providing direct employment to over 45 million and 60 million people indirectly. The Indian Textile Industry contributes approximately 5 per cent to GDP, and 14 per cent to overall Index of Industrial Production (IIP). It is also one of the largest contributing sectors of India's exports contributing 11 per cent to the country's total exports basket. The textiles industry is labour intensive and is one of the largest employers. The textile industry's export earnings were US\$ 41.57 billion in 2013-14 (Texmin, 2015b).

This study explores the potential of the textile industry based on statistics provided by the ministry of textiles. The paper is built around the objective of examining the spread of enterprises in the unincorporated textile sector of India and analyses the concentration of unincorporated textile enterprises in states of India. The data for analysis has been taken from the 67th round of National Sample Survey conducted by the Ministry of Statistics and Planning, Government of India.

Study attempts to provide a picture of informal economy across Indian states of unorganized/unincorporated textile sector. The study also provides a cross-state concentration of textile units and types of enterprises.

\section{Review of the Potential of the Textile Sector in India}

Potential of the Textile Sector in India can be assessed from the statistics behind the success of the textile sector in india and initiatives undertaken by the government of India for strengthening the textile sector and possibility of its growth

\section{Statistics behind Present and Future Potential of the Textile Sector in India}

Textile enterprises form an important indirect link between customers all around the world and weavers and textile workers, as they employ a large segment of the population in India. Strong domestic as well as export demand for textiles lends it further significance. According to India Brand Equity Foundation (IBEF, 2014), a trust established by the Department of Commerce, Ministry of Commerce and Industry, Government of India, India is the second largest producer of textiles and garments in the world.

India has the double advantage on the production front as well as the raw material input segment of natural fibres. It is the 2 nd largest textile manufacturer in the world and also the 2nd largest producer of silk and cotton. In the textile sector $24 \%$ of the world's spindles and $8 \%$ of the world's rotors belong to India. Not surprisingly India has also garnered $63 \%$ of the world's market share in textiles and garments. The domestic textile and apparel industry in India is estimated to reach USD 100 billion by 201617 from USD 67 billion in 2013-14. The potential of the textile sector according to the Ministry of Textiles augments the importance of the industry. Exports in textiles and apparel from India are expected to increase to USD 65 Billion by 2016-17 from USD 40 Billion in 2013-14. The total fabric production in India is expected to grow to 112 billion square metres by 201617 from 64 billion square metres in 2013-14, while India's fibre production in 2013-14 is 7 million tonnes and is expected to reach 10 million tonnes in 2016-17 (Texmin, 2014, IBEF, 2015). 
India is the second largest producer of textiles and garments in the world. The Indian textiles and apparel industry is expected to grow to a size of US\$ 223 billion by 2021 . This industry accounts for almost $24 \%$ of the world's spindle capacity and $8 \%$ of global rotor capacity. Abundant availability of raw materials such as cotton, wool, silk and jute as well as skilled workforce have made the country a sourcing hub (Texmin, 2014, IBEF, 2015).

Man-made fibres (MMF) in the Indian textiles industry has resulted into significant contribution in enhancing the image and bolstering the industry. India has effectively placed its innovative range of MMF textiles in almost all the countries across the globe and it has resulted into a significant increase in MMF production in India by 4 per cent during the period between April 2013 and Feb. 2014. Cotton yarn production increased by about 10 per cent during April 2013-February 2014 while blended and 100 per cent non-cotton yarn production increased by 8 per cent during the period April 2013-February 2014. Cloth production by mill sector registered a growth of 6 per cent during April 2013February 2014 while cloth production by power loom and hosiery increased by 2 per cent and 9 per cent, respectively, during February 2014. The total cloth production grew by 3 per cent during the period April 2013-February 2014 (Texmin, 2014, IBEF, 2015).

The performance and potential on the domestic, export and foreign investment front also enhances the importance of the sector. The domestic textile and apparel industry in India is estimated to reach USD 100 billion by 2016-17 from USD 67 billion in 2013-14, The total fabric production in India is expected to grow to 112 billion square metres by 2016-17 from 64 billion square metres in 2013-14, while India's fibre production in 2013-14 is 7 million tonnes and is expected to reach 10 million tonnes in 2016-17. Textiles exports stood at US\$ 28.53 billion during April 2013January 2014 as compared to US\$ 24.90 billion during the corresponding period of the previous year, registering a growth of 14.58 per cent. Garment exports from India are expected to touch US\$ 60 billion over the next three years, with the help of government support according to Apparel Export Promotion Council, the textiles sector has witnessed a spurt in investment during the last five years. Exports in textiles and apparel from India are expected to increase to USD 65 Billion by 2016-17 from USD 40 Billion in 2013-14 Moreover the industry (including dyed and printed) attracted foreign direct investment (FDI) worth Rs 6,710.94crore (US\$ 1.11 billion) during April 2000 to February 2014. (Texmin, 2014, IBEF, 2015). The Indian textile industry has the potential to grow five-fold over the next ten years to touch US\$ 500 billion mark. The US\$ 500 billion market figure consists of domestic sales of US\$ 315 billion and exports of US\$ 185 billion. The current industry size comprises domestic market of US\$ 68 billion and exports of US\$ 40 billion, Apparel exports from India have registered a growth of 17.6 per cent in the period April-Sept. 2014 over the same period in the previous financial year. The textiles sector has witnessed a spurt in investment during the last five years. The industry (including dyed and printed) attracted foreign direct investment (FDI) worth US\$ 1,522.51 million during April 2000 to December 2014 (Texmin, 2015a and Texmin, 2015b).

Initiatives by the Government of India for enhancing the Potential of the Textile Sector

Ministry of Textiles, Department of Industrial Policy and Promotion, Apparel 
Export Promotion Council (AEPC), National Manufacturing Competitiveness Council (NMCC) etc. try to achieve the targets envisioned in the Textiles Vision document which projects textiles export to touch US\$ 300 billion by the year 2024-25 (NMCC) through specific policies and programmes

The various initiatives are Make in India, an initiative program of the Government of India to encourage companies to manufacture their products in India has been trying to give a boost to the manufacturing of textiles, Technology Upgradation Fund Scheme which has resulted in investment of more than INR 2500 billion in the industry. Support has also been provided for modernisation and upgradation through easy credit at reduced rates and capital subsidies, Scheme for Integrated Textile Parks for providing world class infrastructure to new textile units. To date, 57 Textile Parks have been sanctioned with an investment of INR 60 billion. By 2017, 25 more Textile Parks are to be sanctioned, Integrated Processing Development Scheme for sanctioning processing of textile parks has been initiated to make the process smooth. INR 5 billion has been earmarked for this scheme while Integrated Skill Development Scheme has provided training to 1.5 million people to cover all sub-sectors of textiles such as Textile and Apparel, Handicrafts, Handlooms, Jute and Sericulture. As per the plan for 2012-17, the Integrated Skill Development Scheme aims to train over $2,675,000$ people up to 2017 , covering all sub-sectors of the textile sector textiles and apparel, handicrafts, handlooms, jute and sericulture (Makeinindia, 2015).

The export promotion policies for the textiles sector by the Indian government are duty free entitlement to garment exporters for import of trimmings, embellishments and other specified items increased from 3 per cent to 5 per cent. This initiative is expected to generate an additional RMG (Readymade garments) exports estimated at Rs 10,000 crore (US\$ 1.61 billion). The government has also proposed to extend round-the-clock customs clearance facility at 13 airports and 14 sea ports resulting in faster clearance of import and export cargo. The proposal for imposing duty on branded items was dropped providing relief to the entire value chain. The Ministry of Textiles has approved a 'Scheme for promoting usage of geotechnical textiles in North East Region (NER) in order to capitalise on the benefits of geotechnical textiles. The scheme has been approved with a financial outlay of Rs 427 crore (US\$ 69.12 million) for five years from 2014-15. Technical Textiles sector is one of the fastest growing segments of the Indian economy. It has registered a compounded annual rate of growth of $11 \%$ during the period 2007-2012 as per estimates the technical textiles market size is expected to reach US \$26 billion (INR $1,58,540$ crore) by $2016-17$ from the market size of US \$ 11.6 billion (INR 70,151 crore) in 2012-13. Market size in the current year is projected at US \$ 18.2 billion (INR 1,09,659 crore) (IBEF, 2015).

The Ministry of Textiles, Government of India also plans to enter into an agreement with Flipkart to provide an online platform to handloom weavers to sell their products. Trade Facilitation Centre and Craft Museum has been initiated in Varanasi. Moreover detailed arrangement for purchase of cotton from the farmers by the Cotton Corporation of India Ltd (CCI) under the Minimum Support Price Operation is monitored. 343 purchase centers were finalised in consultation with the State Governments after meetings with officers of CCI and the cotton producing states, resulting in streamlining of operations. Ministry has also 
allowed 100 per cent FDI in the Indian textiles sector under the automatic route (PIB, 2015abc, IBEF, 2015). While the first National Handloom Day was launched on 7th August, 2015 and India International Garment Fair was held recently apart from many government textile exhibitions and fairs that are promoted.

\section{Objective of the Study}

- To examine the spread of enterprises in the unincorporated textile sector of India

- To analyse the concentration of different textile enterprises in the unincorporated sector

across states of India

- To assess the potential of textile enterprises in the unincorporated textile sector across states of India

\section{Data and Research Methodology}

Data has been sourced from Ministry of Textile, Government of India and the 'Survey of Unincorporated Non-agricultural Enterprises (Excluding Construction) in India', National Sample Survey, Ministry Of Statistics and Planning, Government of India under its NSS $67^{\text {th }}$ round (2010-2011).

The coverage of NSS 67th round (July 2010 - June 2011) was non-agricultural unincorporated enterprises considered the manufacturing enterprises the following ownership categories of enterprises were excluded from the coverage of the unincorporated sector survey: (a) Enterprises which are incorporated i.e. registered under Companies Act, 1956, (b) Government and public sector enterprises and (c) Cooperatives.

Entire analysis is based in the enterprises engaged in textile manufacturing within the unincorporated enterprises of India and the unit level data has been analysed through STATA for data extraction and further statistical analysis has also been undertaken.

\section{Analysis of the Spread of Unincorporated Textile Enterprises among States of India}

The textile industry has two broad segments, namely handloom, handicrafts, sericulture, power looms in the unorganized/unincorporated sector and spinning, apparel, garmenting, made ups in the organized/incorporated sector. The Indian textiles industry is extremely varied, with a hand-spun and handwoven sector at one end of the spectrum, and the capital intensive sophisticated mill sector at the other. The decentralised power looms/ hosiery and knitting sector form the largest and knitting sector form the largest section of the Textiles Sector. The close linkage of the Industry to agriculture and the ancient culture, the traditions of the country make the Indian textiles sector unique in comparison to the textiles industry of other countries. This also provides the industry with the capacity to produce a variety of products suitable to the different market segments, both within and outside the country (Texmin, 2015a, Texmin, 2015b).

The unincorporated sector comprises of Textiles as per NIC (National Industrial Classification) 2008, which are concerned with the important areas of Spinning, Weaving and Finishing of Textiles, NIC 131 and Manufacture of Other Textiles, NIC 139 both have been analysed according to the $67^{\text {th }}$ round NSSO survey 2011 unit level data released and extracted in 2014.

It can be assessed from the table 1 that Spinning, Weaving and Finishing of Textiles NIC 131 is less than the number of enterprises under Manufacture of Other Textiles NIC 139 in India, though 
traditionally NIC131 dominated the textile scene in the pre-independence period. This also signals the fast development of manufacturing in India since India has a large consumer base for textile consumption as end products and intermediaries.

On analysing the data further we assess that the unincorporated textile enterprises dominant states of West Bengal, Uttar Pradesh and Gujarat have a higher concentration of Manufacture of Other Textiles NIC 139 while the seven north eastern states of Assam, Manipur, Nagaland, Tripura, Meghalaya, Arunachal Pradesh and Mizoram are dominated by NIC131 enterprises and so are the four southern states of Tamil Nadu, Andhra Pradesh, Karnataka and Kerala.

\section{Further classification of NIC 131 and its Interstate Variation}

The unincorporated textile sector covers diverse areas. According to National Industrial Code (NIC) (Nath, 2008) it includes Preparation and spinning of textile fibres (NIC 1311), Weaving of textiles (NIC 1312) and Finishing of textiles (NIC 1313). These are further classified as under (Nath, 2008)

\section{Preparation and spinning of textile fibers}

13111 Preparation and spinning of cotton fiber including blended* cotton

13112 Preparation and spinning of silk fiber including blended* silk

13113 Preparation and spinning of wool, including other animal hair and blended*wool including other animal hair 13114 Preparation and spinning of manmade fiber including blended* man-made fiber
13119 Preparation and spinning of jute, mesta and other natural fibers including blended natural fibers n.e.c.

*Blended yarn/fabrics means, yarn/fabrics containing more than $50 \%$ of one fiber.

\section{Weaving of textiles}

13121 Weaving, manufacture of cotton and cotton mixture fabrics.

13122 Weaving, manufacture of silk and silk mixture fabrics.

13123 Weaving, manufacture of wool and wool mixture fabrics.

13124 Weaving, manufacturing of manmade fiber and man-made mixture fabrics.

13129 Weaving of jute, mesta and other natural fibers including blended naturalfibers n.e.c.

\section{Finishing of textiles}

13131 Finishing of cotton and blended cotton textiles.

13132 Finishing of silk and blended silk textiles.

13133 Finishing of wool and blended wool textiles.

13134 Finishing of man-made and blended man-made textiles.

13135 Finishing of jute, mesta and other vegetable textiles fabrics

13136 Activity related to screen printing

13139 Other activities relating to finishing of textile n.e.c.

It can be assessed from table 2 that for classifications under Spinning, Weaving and Finishing of Textiles (NIC 131), it is Weaving of textiles (NIC 1312) which dominates with four times the number of enterprises than Preparation and spinning of textile fibres (NIC 1311) and Finishing of textiles (NIC 1313). India does not have a shortage of work force for preparation and spinning of textile fibres and the shortage of 
number of enterprises in this class could be due to import of fibres or replacement of manmade fibres. The section of population associated with NIC1311 is a vulnerable lot and the government should try to redress their inability to revive their craft. Under Finishing of Textiles (NIC 1313), the enterprises are larger and this could be a reason for less number of enterprises in this classification as well these enterprises could be in the organized/incorporated sector (appendix for sub-classification).

On analysing the data further we assess that the unincorporated textile enterprises dominant states of West Bengal, Uttar Pradesh and Gujarat have a diverse spread of textile enterprise classification with West Bengal has a concentration of Preparation and Spinning of Textile Fibres (NIC 1311), while Uttar Pradesh is populated by Weaving of Textiles, (NIC 1312) and Gujarat is dominated by Finishing of Textiles (NIC 1313) enterprises. The seven north eastern states of Assam, Manipur, Nagaland, Tripura, Meghalaya, Arunachal Pradesh and Mizoram have a concentration of NIC1312. The four southern states of Tamil Nadu, Andhra Pradesh, Karnataka and Kerala differ in their concentration of textile enterprises, Tamil Nadu has a higher concentration of NIC 1312 and NIC 1313 enterprises, Andhra Pradesh and Karnataka have a higher concentration of NIC 1311 and NIC 1312 while Kerala is dominated by NIC 1311.

\section{Further classification of NIC 139 and its Interstate Variation}

The unincorporated textile enterprises classification NIC 139 covers diverse areas. According to National Industrial Code (NIC) it includes Manufacture of knitted and crocheted fabrics (NIC 1391), Manufacture of made-up textile articles except apparel
(NIC 1392), Manufacture of carpets and rugs (NIC 1393), Manufacture of cordage, rope, twine and netting (NIC 1394), and Manufacture of other textiles n.e.c. (NIC 1399). These are further classified as under (Nath, 2008)

\section{Manufacture of knitted and crocheted fabrics}

13911 Manufacture of knitted and crocheted cotton fabrics

13912 Manufacture of knitted and crocheted woolen fabrics

13913 Manufacture of knitted and crocheted synthetic fabrics

13919 Manufacture of other knitted and crocheted fabrics

\section{Manufacture of made-up textile articles, except apparel}

13921 Manufacture of curtains, bed covers and furnishings

13922 Manufacture of crocheted made up textile goods except apparel

13923 Manufacture of mosquito nets 13924 Manufacture of bedding, quilts pillows, sleeping bags etc.

13925 Manufacture of tarpaulin

13926 Manufacture of blankets

13929 Manufacture of other made-up textile articles, except apparel n.e.c.

\section{Manufacture of carpets and rugs}

13931 Manufacture of carpets and other floor coverings made of cotton 13932 Manufacture of carpets and other floor coverings made of wool 13933 Manufacture of carpets and other floor coverings made of silk

13934 Manufacture of carpets made of synthetic materials

13935 Manufacture of carpets, and other floor coverings made of jute, mesta andcoir 
Int.J.Curr.Res.Aca.Rev.2016; 4(11): 142-156

13939 Manufacture of other floor coverings n.e.c.

\section{Manufacture of cordage, rope, twine and netting}

13941 Manufacture of thread, including thread ball making

13942 Manufacture of cordage or rope made of jute

13943 Manufacture of cordage or rope made of coir

13944 Manufacture of rope and cordage made of synthetic material

13945 Manufacture of knotted netting of twine, cordage or rope (other than mosquito net)

13946 Manufacture of tapes, newar and wicks

13949 Manufacture of other cordage or rope n.e.c.

\section{Manufacture of other textiles n.e.c.}

13991 Embroidery work and making of laces and fringes

13992 Zari work and other ornamental trimmings

13993 Manufacture of linolium and similar products

13994 Manufacture of gas mantles

13995 Manufacture of made-up canvas goods such tents, sails etc.

13996 Manufacture of wadding of textile materials and articles of wadding such as sanitary napkins and tampoons

13997 Manufacture of metallised yarn or gimped yarn, rubber thread or cord covered with textile material, textile yarn or strip impregnated, covered or sheathed with rubber or plastic

13998 Manufacture of waterproof textile excluding tarpaulin

13999 Manufacture of other textiles/textile products n.e.c.
It can be assessed from table 3 that for Manufacture of Other Textiles NIC 139 Sub-classifications, it is Manufacture of other textiles n.e.c. (NIC 1399) which dominates with almost nine times the number enterprises in other subclassifications that is Manufacture of knitted and crocheted fabrics (NIC 1391), Manufacture of made-up textile articles except apparel (NIC 1392), Manufacture of carpets and rugs (NIC 1393), Manufacture of cordage, rope, twine and netting (NIC 1394). This is also due to NIC 1399 being a broad classification.

North Indian state of Punjab dominates the Manufacture of knitted and crocheted fabrics (NIC 1391) sub-classification with the number of enterprises and is followed by Rajasthan, Tamil Nadu and Uttar Pradesh.

On analysing the data further, we assess that the unincorporated textile enterprises dominant states of West Bengal, Uttar Pradesh and Gujarat dominate the scene here also and have a diverse spread of textile enterprise sub-classification with West Bengal and Gujarat having a concentration of Manufacture of made-up textile articles except apparel (NIC 1392) and Manufacture of other textiles n.e.c. (NIC 1399), while Uttar Pradesh has a concentration of Manufacture of carpets and rugs (NIC 1393) enterprises and dominates the NIC 1399 class.

The seven north eastern states of Assam, Manipur, Nagaland, Tripura, Meghalaya, Arunachal Pradesh and Mizoram are almost limited to NIC 1392 enterprises. The four southern states of Andhra Pradesh, Tamil Nadu, Kerala and Karnataka differ in their concentration of textile enterprises, Andhra Pradesh has a higher concentration of NIC 1392, NIC 1394 and NIC 1399, Tamil Nadu has a higher concentration of NIC 1393 and 
Int.J.Curr.Res.Aca.Rev.2016; 4(11): 142-156

NIC 1394 and NIC 3199 enterprises, while Kerala is dominated by NIC 1393 enterprises. Kerala and Tamil Nadu are behind only Uttar Pradesh and Jammu and Kashmir in Manufacture of carpets and rugs (NIC 1393). Andhra Pradesh has a higher concentration of NIC 1399 enterprises.

\section{Potential of Unincorporated Textile Enterprises across States}

Potential of unincorporated textile enterprises is based on employment generation and gross Value Addition (GVA) among different states since textile manufacturing is the second largest employer in India employing 5.8 million persons in 2011, with more than 2.5 of them being women. The textile sector is spread across states and manufacturing enterprises are located at remote areas even in places where electricity is unavailable. Therefore it provides employment to vulnerable section of the population. The five dominant states in terms of number of enterprises employ a large section of the working force, with Uttar Pradesh and West Bengal employing more than 10 million persons each, Gujarat and Tamil Nadu employ between 8-10 million persons while Andhra Pradesh employs almost half a million persons.

GVA generated by the states presents a picture of a vibrant and successful textile sector in the unincorporated manufacturing sector with high potential for further development.

Table.1 Interstate Variation in the Concentration of Textile Enterprises according to Two Major Classifications

\begin{tabular}{|c|c|c|c|}
\hline \multirow{2}{*}{$\begin{array}{l}\text { STATES OF INDIA } \\
\text { WITH DECREASING } \\
\text { NUMBER OF TOTAL } \\
\text { ENTERPRISES }\end{array}$} & \multicolumn{3}{|c|}{$\begin{array}{l}\text { NUMBER OF ENTERPRISES AND ITS CORRESPONDING } \\
\text { PERCENTAGE• }\end{array}$} \\
\hline & $\begin{array}{l}\text { SPINNING, WEAVING } \\
\text { AND FINISHING OF } \\
\text { TEXTILES (NIC 131) }\end{array}$ & $\begin{array}{l}\text { MANUFACTURE OF } \\
\text { OTHER TEXTILES } \\
\text { (NIC 139) }\end{array}$ & $\begin{array}{l}\text { TOTAL } \\
\text { ENTERPRISES IN } \\
\text { THE STATES }\end{array}$ \\
\hline \multirow[t]{2}{*}{ WEST BENGAL } & 100,922 & 545,249 & 646,171 \\
\hline & $10.81 \%$ & $31.93 \%$ & $24.46 \%$ \\
\hline \multirow[t]{2}{*}{ UTTAR PRADESH } & 73,368 & 416,396 & 489,765 \\
\hline & $7.86 \%$ & $24.38 \%$ & $18.54 \%$ \\
\hline \multirow[t]{2}{*}{ GUJARAT } & 90,248 & 315,705 & 405,953 \\
\hline & $9.66 \%$ & $18.49 \%$ & $15.37 \%$ \\
\hline \multirow[t]{2}{*}{ TAMIL NADU } & 240,259 & 45,259 & 285,519 \\
\hline & $25.73 \%$ & $2.65 \%$ & $10.81 \%$ \\
\hline \multirow[t]{2}{*}{ ANDHRA PRADESH } & 134,241 & 67,996 & 202,238 \\
\hline & $14.37 \%$ & 3.98 & 7.66 \\
\hline \multirow[t]{2}{*}{ JAMMU \& KASHMIR } & 38,717 & 48,237 & 86,953 \\
\hline & $4.15 \%$ & $2.82 \%$ & $3.29 \%$ \\
\hline \multirow{2}{*}{ PUNJAB } & 5,890 & 63,441 & 69,331 \\
\hline & $0.63 \%$ & $3.71 \%$ & 2.62 \\
\hline \multirow{2}{*}{ ORISSA } & 42,770 & 20,143 & 62,913 \\
\hline & $4.58 \%$ & $1.18 \%$ & $2.38 \%$ \\
\hline \multirow[t]{2}{*}{ RAJASTHAN } & 21,020 & 38,770 & 59,790 \\
\hline & $2.25 \%$ & $2.27 \%$ & $2.26 \%$ \\
\hline \multirow[t]{2}{*}{ MAHARASHTRA } & 8,005 & 49,271 & 57,276 \\
\hline & $0.86 \%$ & $2.89 \%$ & $2.17 \%$ \\
\hline \multirow[t]{2}{*}{ KARNATAKA } & 48,255 & 5,570 & 53,825 \\
\hline & $5.17 \%$ & $0.33 \%$ & $2.04 \%$ \\
\hline
\end{tabular}


Int.J.Curr.Res.Aca.Rev.2016; 4(11): 142-156

\begin{tabular}{|c|c|c|c|}
\hline \multirow[t]{2}{*}{ KERALA } & 37,098 & 15,628 & 52,727 \\
\hline & $3.97 \%$ & $0.92 \%$ & 2.00 \\
\hline \multirow[t]{2}{*}{ ASSAM } & 37,715 & 3,460 & 41,175 \\
\hline & $4.04 \%$ & $0.20 \%$ & $1.56 \%$ \\
\hline \multirow{2}{*}{ MADHYA PRADESH } & 3,189 & 28,667 & 31,856 \\
\hline & $0.34 \%$ & $1.68 \%$ & $1.21 \%$ \\
\hline \multirow{2}{*}{ MANIPUR } & 27,018 & 3,956 & 30,974 \\
\hline & $2.89 \%$ & $0.23 \%$ & $1.17 \%$ \\
\hline \multirow[t]{2}{*}{ DELHI } & 1,257 & 14,003 & 15,261 \\
\hline & $0.13 \%$ & $0.82 \%$ & $0.58 \%$ \\
\hline \multirow{2}{*}{ JHARKHAND } & 8,296 & 2,033 & 10,329 \\
\hline & $0.89 \%$ & $0.12 \%$ & $0.39 \%$ \\
\hline \multirow[t]{2}{*}{ BIHAR } & 5,075 & 3,926 & 9,000 \\
\hline & $0.54 \%$ & $0.23 \%$ & $0.34 \%$ \\
\hline \multirow[t]{2}{*}{ HARYANA } & 401 & 7,227 & 7,628 \\
\hline & $0.04 \%$ & $0.42 \%$ & $0.29 \%$ \\
\hline \multirow[t]{2}{*}{ UTTARANCHAL } & $1,536.34$ & $4,627.95$ & $6,164.28$ \\
\hline & $0.16 \%$ & $0.27 \%$ & $0.23 \%$ \\
\hline \multirow{2}{*}{ HIMACHAL PRADESH } & 1,022 & 3,751 & 4,773 \\
\hline & $0.11 \%$ & $0.22 \%$ & $0.18 \%$ \\
\hline \multirow[t]{2}{*}{ NAGALAND } & 3,003 & 36 & 3,040 \\
\hline & $0.32 \%$ & - & $0.12 \%$ \\
\hline \multirow{2}{*}{ CHHATTISGARH } & 425 & 2,454 & 2,879 \\
\hline & $0.05 \%$ & $0.14 \%$ & $0.11 \%$ \\
\hline \multirow[t]{2}{*}{ TRIPURA } & 1,951 & 555 & 2,506 \\
\hline & $0.21 \%$ & $0.03 \%$ & $0.09 \%$ \\
\hline \multirow{2}{*}{ MEGHALAYA } & 1,503 & 145 & 1,648 \\
\hline & $0.16 \%$ & $0.01 \%$ & $0.06 \%$ \\
\hline \multirow[t]{2}{*}{ DAMAN \& DIU } & - & 643 & 643 \\
\hline & - & 0.04 & 0.02 \\
\hline \multirow[t]{2}{*}{ PONDICHERRY } & 372 & 263 & 636 \\
\hline & $0.04 \%$ & $0.02 \%$ & $0.02 \%$ \\
\hline \multirow{3}{*}{$\begin{array}{l}\text { ARUNACHAL } \\
\text { PRADESH }\end{array}$} & & & \\
\hline & 247 & 57 & 303 \\
\hline & $0.03 \%$ & - & $0.01 \%$ \\
\hline \multirow[t]{2}{*}{ CHANDIGARH } & 24 & 149 & 173 \\
\hline & - & $0.01 \%$ & $0.01 \%$ \\
\hline \multirow[t]{2}{*}{ SIKKIM } & - & 123 & 123 \\
\hline & - & $0.01 \%$ & - \\
\hline \multirow[t]{2}{*}{ MIZORAM } & 57.50 & 19.13 & 76.63 \\
\hline & $0.01 \%$ & - & - \\
\hline \multirow[t]{2}{*}{ GOA } & - & 24 & 24 \\
\hline & - & - & - \\
\hline \multirow[t]{2}{*}{ D \& N HAVELI } & - & 14 & 14 \\
\hline & - & - & - \\
\hline \multirow[t]{2}{*}{ A \& N ISLANDS } & 2 & - & 2 \\
\hline & - & - & - \\
\hline TOTAL & 933,885 & $1,707,798$ & $2,641,683$ \\
\hline & $100 \%$ & $100 \%$ & $100 \%$ \\
\hline
\end{tabular}

- A short dash (-) indicates "not applicable as data is too low or the criterion is not applicable" 
Int.J.Curr.Res.Aca.Rev.2016; 4(11): 142-156

Table.2 Interstate Variation in the Concentration of Unincorporated Textile Enterprises according to Spinning, Weaving and Finishing of Textiles (NIC 131) Sub-classifications

\begin{tabular}{|c|c|c|c|}
\hline \multirow{2}{*}{$\begin{array}{l}\text { STATES OF INDIA WITH } \\
\text { DECREASING NUMBER } \\
\text { OF TOTAL } \\
\text { ENTERPRISES IN NIC } \\
131 \text { CLASSIFICATION }\end{array}$} & \multicolumn{3}{|c|}{$\begin{array}{l}\text { NUMBER OF ENTERPRISES AND ITS CORRESPONDING } \\
\text { PERCENTAGE • }\end{array}$} \\
\hline & $\begin{array}{l}\text { PREPARATION } \\
\text { AND SPINNING OF } \\
\text { TEXTILE FIBRES } \\
\text { (NIC 1311) }\end{array}$ & $\begin{array}{l}\text { WEAVING OF } \\
\text { TEXTILES } \\
\text { (NIC 1312) }\end{array}$ & $\begin{array}{l}\text { FINISHING OF } \\
\text { TEXTILES } \\
\text { (NIC 1313) }\end{array}$ \\
\hline \multirow[t]{2}{*}{ TAMIL NADU } & 5,731 & 202,450 & 320,789 \\
\hline & $3.96 \%$ & $31.49 \%$ & $21.90 \%$ \\
\hline \multirow[t]{2}{*}{ ANDHRA PRADESH } & 15,270 & 117,843 & 1,129 \\
\hline & $10.56 \%$ & $18.33 \%$ & $0.77 \%$ \\
\hline \multirow[t]{2}{*}{ WEST BENGAL } & 21,615 & 71,689 & 7,618 \\
\hline & $14.95 \%$ & $11.15 \%$ & $5.20 \%$ \\
\hline \multirow[t]{2}{*}{ GUJARAT } & 1,483 & 19,497 & 69,268 \\
\hline & $1.03 \%$ & $3.03 \%$ & $47.30 \%$ \\
\hline \multirow[t]{2}{*}{ UTTAR PRADESH } & 5,758 & 61,465 & 6,145 \\
\hline & $3.98 \%$ & $9.56 \%$ & $4.20 \%$ \\
\hline \multirow[t]{2}{*}{ KARNATAKA } & 7,298 & 37,878 & 3,079 \\
\hline & $5.05 \%$ & $5.89 \%$ & $2.10 \%$ \\
\hline \multirow[t]{2}{*}{ ORISSA } & 1,406 & 39,199 & 2,165 \\
\hline & $0.97 \%$ & $6.10 \%$ & $1.48 \%$ \\
\hline \multirow[t]{2}{*}{ JAMMU \& KASHMIR } & 33,703 & 4,886 & 128 \\
\hline & $23.31 \%$ & $0.76 \%$ & $0.09 \%$ \\
\hline \multirow[t]{2}{*}{ ASSAM } & 1,039 & 34,774 & 1,903 \\
\hline & $0.72 \%$ & $5.41 \%$ & $1.30 \%$ \\
\hline \multirow[t]{2}{*}{ KERALA } & 34,719 & 2,263 & 116 \\
\hline & $24.02 \%$ & $0.35 \%$ & $0.08 \%$ \\
\hline \multirow[t]{2}{*}{ MANIPUR } & 375 & 25,513 & 1,130 \\
\hline & $0.26 \%$ & $3.97 \%$ & $0.77 \%$ \\
\hline \multirow[t]{2}{*}{ RAJASTHAN } & 4,615 & - & 16,405 \\
\hline & $3.19 \%$ & - & $11.20 \%$ \\
\hline \multirow[t]{2}{*}{ JHARKHAND } & 6,116 & 2,180 & 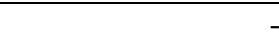 \\
\hline & $4.23 \%$ & $0.34 \%$ & 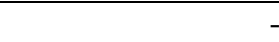 \\
\hline \multirow[t]{2}{*}{ MAHARASHTRA } & 182 & 6,867 & 955 \\
\hline & $0.13 \%$ & $1.07 \%$ & $0.65 \%$ \\
\hline \multirow[t]{2}{*}{ PUNJAB } & 350 & 2,432 & 3,108 \\
\hline & $0.24 \%$ & $0.38 \%$ & $2.12 \%$ \\
\hline \multirow[t]{2}{*}{ BIHAR } & 4,315 & 738 & 22 \\
\hline & $2.98 \%$ & $0.11 \%$ & $0.01 \%$ \\
\hline \multirow[t]{2}{*}{ MADHYA PRADESH } & 40 & 3,018 & 131 \\
\hline & $0.03 \%$ & $0.47 \%$ & $0.09 \%$ \\
\hline \multirow[t]{2}{*}{ NAGALAND } & 10 & 2,96 & 31 \\
\hline & $0.01 \%$ & $0.46 \%$ & $0.02 \%$ \\
\hline \multirow[t]{2}{*}{ TRIPURA } & - & 1,951 & 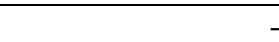 \\
\hline & - & $0.30 \%$ & - \\
\hline \multirow[t]{2}{*}{ UTTARANCHAL } & - & 1,536 &  \\
\hline & - & $0.24 \%$ & 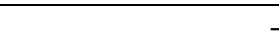 \\
\hline \multirow[t]{2}{*}{ MEGHALAYA } & - & 1,503 & - \\
\hline &  & $0.23 \%$ & 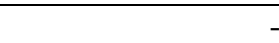 \\
\hline \multirow[t]{2}{*}{ DELHI } & 253.14 & 75 & 928.69 \\
\hline & $0.18 \%$ & $0.01 \%$ & 0.63 \\
\hline
\end{tabular}


Int.J.Curr.Res.Aca.Rev.2016; 4(11): 142-156

\begin{tabular}{|l|r|r|r|}
\hline HIMACHAL PRADESH & 48 & 950 & \multicolumn{1}{|c|}{24} \\
\hline CHHATTISGARH & $0.03 \%$ & $0.15 \%$ & $0.02 \%$ \\
\hline & - & - & 24 \\
\hline HARYANA & - & - & 0.02 \\
\hline PONDICHERRY & 232 & 136 & 33 \\
\hline & $0.16 \%$ & $0.02 \%$ & $0.02 \%$ \\
\hline ARUNACHAL PRADESH & - & 353 & 19 \\
\hline & - & $0.05 \%$ & $0.01 \%$ \\
\hline MIZORAM & - & 247 & - \\
\hline & - & $0.04 \%$ & - \\
\hline CHANDIGARH & - & 58 & - \\
\hline & - & $0.01 \%$ & -23.89 \\
\hline A \& N ISLANDS & - & - & 0.02 \\
\hline & - & - & - \\
\hline TOTAL & - & 2 & - \\
\hline & - & - & 146,453 \\
\hline
\end{tabular}

- A short dash (-) indicates "not applicable as data is too low or the criterion is not applicable"

Table.3 Interstate Variation in the Concentration of Unincorporated Textile Enterprises according to Manufacture of Other Textiles NIC 139 Sub-classifications

\begin{tabular}{|c|c|c|c|c|c|}
\hline \multirow[b]{2}{*}{$\begin{array}{l}\text { States of India with } \\
\text { decreasing number } \\
\text { of total enterprises } \\
\text { in NIC } 139 \\
\text { classification }\end{array}$} & \multicolumn{5}{|c|}{ Number of enterprises and its corresponding percentage• } \\
\hline & $\begin{array}{l}\text { Manufacture } \\
\text { of knitted and } \\
\text { crocheted } \\
\text { fabrics } \\
\text { (NIC 1391) }\end{array}$ & $\begin{array}{l}\text { Manufacture } \\
\text { of made-up } \\
\text { textile articles } \\
\text { except apparel } \\
\text { (NIC 1392) }\end{array}$ & $\begin{array}{l}\text { Manufacture } \\
\text { of carpets } \\
\text { and rugs } \\
\text { (NIC 1393) }\end{array}$ & $\begin{array}{l}\text { Manufacture } \\
\text { of cordage, } \\
\text { rope, twine } \\
\text { and netting } \\
\text { (NIC 1394) }\end{array}$ & $\begin{array}{l}\text { Manufactur } \\
\text { e of other } \\
\text { textiles } \\
\text { n.e.c. } \\
\text { (NIC 1399) }\end{array}$ \\
\hline \multirow[t]{2}{*}{ West Bengal } & 1,932 & 31,305 & 5,654 & 42,266 & 464,094 \\
\hline & $6.05 \%$ & $22.87 \%$ & $4.33 \%$ & $36.89 \%$ & $35.87 \%$ \\
\hline \multirow[t]{2}{*}{ Uttar Pradesh } & 3,219 & 10,492 & 79,736 & 19,082 & 303,870 \\
\hline & $10.07 \%$ & $7.66 \%$ & $61.00 \%$ & $16.66 \%$ & $23.49 \%$ \\
\hline \multirow[t]{2}{*}{ Gujarat } & - & 13,696 & 22 & 3,196 & 298,791 \\
\hline & - & $10.01 \%$ & $0.02 \%$ & $2.79 \%$ & $23.10 \%$ \\
\hline \multirow[t]{2}{*}{ Andhra Pradesh } & 11 & 6,869 & 2,494 & 5,823 & 52,800 \\
\hline & $0.04 \%$ & $5.02 \%$ & $1.91 \%$ & $5.08 \%$ & $4.08 \%$ \\
\hline \multirow[t]{2}{*}{ Punjab } & 12,255 & 3,738 & 149 & 696 & 46,603 \\
\hline & $38.36 \%$ & $2.73 \%$ & $0.11 \%$ & $0.61 \%$ & $3.60 \%$ \\
\hline \multirow[t]{2}{*}{ Maharashtra } & - & 29,209 & 140 & 3,102 & 16,820 \\
\hline & - & $21.34 \%$ & $0.11 \%$ & $2.71 \%$ & $1.30 \%$ \\
\hline \multirow[t]{2}{*}{ Jammu\&Kashmir } & 159 & 480 & 14,257 & - & 33,340 \\
\hline & $0.50 \%$ & $0.35 \%$ & $10.91 \%$ & - & $2.58 \%$ \\
\hline \multirow[t]{2}{*}{ Tamil Nadu } & 4,771 & 6,561 & 8,108 & 14,150 & 11,669 \\
\hline & $14.93 \%$ & $4.79 \%$ & $6.20 \%$ & $12.35 \%$ & $0.90 \%$ \\
\hline \multirow[t]{2}{*}{ Rajasthan } & 8,652 & 2,268 & 3,796 & 353 & 23,700 \\
\hline & $27.08 \%$ & $1.66 \%$ & $2.90 \%$ & $0.31 \%$ & $1.83 \%$ \\
\hline \multirow[t]{2}{*}{ Madhya Pradesh } & - & 4,980 & 2,260 & 4,566 & 16,861 \\
\hline &  & $3.64 \%$ & $1.73 \%$ & $3.99 \%$ & $1.30 \%$ \\
\hline Orissa & 14 & 4,084 & 658 & 15,235 & 152 \\
\hline
\end{tabular}


Int.J.Curr.Res.Aca.Rev.2016; 4(11): 142-156

\begin{tabular}{|c|c|c|c|c|c|}
\hline & $0.04 \%$ & $2.98 \%$ & $0.50 \%$ & $13.30 \%$ & $0.01 \%$ \\
\hline \multirow[t]{2}{*}{ Kerala } & - & 2,489 & 8,131 & 3,085 & 1,923 \\
\hline & - & $1.82 \%$ & $6.22 \%$ & $2.69 \%$ & $0.15 \%$ \\
\hline \multirow{2}{*}{ Delhi } & 280 & 1,739 & 89 & 453 & 11,443 \\
\hline & $0.88 \%$ & $1.27 \%$ & $0.07 \%$ & $0.39 \%$ & $0.88 \%$ \\
\hline \multirow[t]{2}{*}{ Haryana } & - & 991 & 3,713 & 293 & 2,230 \\
\hline & - & $0.72 \%$ & $2.84 \%$ & $0.26 \%$ & $0.17 \%$ \\
\hline \multirow[t]{2}{*}{ Karnataka } & - & 3,748 & 24 & 733 & 1,065 \\
\hline & - & $2.74 \%$ & $0.02 \%$ & $0.64 \%$ & $0.08 \%$ \\
\hline \multirow[t]{2}{*}{ Uttaranchal } & - & 1,039 & 856 & - & 2,733 \\
\hline & - & $0.76 \%$ & $0.65 \%$ & - & $0.21 \%$ \\
\hline \multirow[t]{2}{*}{ Manipur } & 6 & 1,195 & - & 20 & 2,735 \\
\hline & $0.02 \%$ & $0.87 \%$ & - & $0.02 \%$ & $0.21 \%$ \\
\hline \multirow[t]{2}{*}{ Bihar } & 169 & 2,054 & 243 & 24 & 1,436 \\
\hline & $0.53 \%$ & $1.50 \%$ & $0.19 \%$ & $0.02 \%$ & $0.11 \%$ \\
\hline \multirow[t]{2}{*}{ Himachal Pradesh } & 448 & 3,048 & 26 & 32 & 197 \\
\hline & $1.40 \%$ & $2.23 \%$ & 0.02 & $0.03 \%$ & 0.02 \\
\hline \multirow[t]{2}{*}{ Assam } & - & 1,950 & - & 774 & 736 \\
\hline & - & $1.42 \%$ & - & $0.68 \%$ & $0.06 \%$ \\
\hline \multirow[t]{2}{*}{ Chhattisgarh } & - & 2,387 & - & - & 67 \\
\hline & - & $1.74 \%$ & - & - & $0.01 \%$ \\
\hline \multirow[t]{2}{*}{ Jharkhand } & - & 1,989 & - & 44 & - \\
\hline & - & $1.45 \%$ & - & $0.04 \%$ & - \\
\hline \multirow[t]{2}{*}{ Daman \& Diu } & - & 29 & - & 561 & 53 \\
\hline & - & $0.02 \%$ & - & $0.49 \%$ & - \\
\hline \multirow[t]{2}{*}{ Tripura } & - & 142 & 286 & - & 127 \\
\hline & - & $0.10 \%$ & $0.22 \%$ & - & $0.01 \%$ \\
\hline \multirow{2}{*}{ Pondicherry } & - & 97 & 39 & 81 & 47 \\
\hline & - & $0.07 \%$ & $0.03 \%$ & $0.07 \%$ & - \\
\hline \multirow[t]{2}{*}{ Chandigarh } & - & 18 & - & - & 131 \\
\hline & - & $0.01 \%$ & - & - & $0.01 \%$ \\
\hline \multirow{2}{*}{ Meghalaya } & - & 98 & - & - & 46 \\
\hline & - & $0.07 \%$ & - & - & - \\
\hline \multirow[t]{2}{*}{ Sikkim } & - & 122.89 & - & - & - \\
\hline & - & $0.09 \%$ & - & - & - \\
\hline \multirow[t]{2}{*}{ Arunachal Pradesh } & - & 21 & 35 & - & - \\
\hline & - & $0.02 \%$ & $0.03 \%$ & - & - \\
\hline \multirow[t]{2}{*}{ Nagaland } & 36 & - & - & - & - \\
\hline & $0.11 \%$ & - & - & - & - \\
\hline \multirow[t]{2}{*}{ Goa } & - & 8 & - & - & 16 \\
\hline & - & $0.01 \%$ & - & - & - \\
\hline \multirow[t]{2}{*}{ Mizoram } & - & 19 & - & - & - \\
\hline & - & $0.01 \%$ & - & - & - \\
\hline \multirow[t]{2}{*}{ D \& N Haveli } & - & 14 & - & - & - \\
\hline & - & $0.01 \%$ & - & - & - \\
\hline \multirow[t]{2}{*}{ TOTAL } & 31,951 & 136,881 & 130,716 & 114,566 & $1,293,685$ \\
\hline & $100 \%$ & $100 \%$ & $100 \%$ & $100 \%$ & $100 \%$ \\
\hline
\end{tabular}

- A short dash (-) indicates "not applicable as data is too less/low or the criterion is not applicable" 
Int.J.Curr.Res.Aca.Rev.2016; 4(11): 142-156

Table.4 Interstate Variation in the Number of Persons Employed and Sum of Positive GVA Generated by the Enterprises NIC 131 and NIC 139 in the Unincorporated Textile Sector

\begin{tabular}{|c|c|c|}
\hline $\begin{array}{l}\text { STATES IN } \\
\text { DECREASING } \\
\text { ORDER OF NUMBER } \\
\text { OF PERSONS } \\
\text { EMPLOYED }\end{array}$ & $\begin{array}{l}\text { NUMBER OF } \\
\text { PERSONS } \\
\text { EMPLOYED• }\end{array}$ & $\begin{array}{l}\text { SUM OF POSITIVE GVA } \\
\text { GENERATED BY THE } \\
\text { ENTERPRISES IN RUPEES• }\end{array}$ \\
\hline UTTAR PRADESH & $1,151,537$ & $1,580,000,000$ \\
\hline WEST BENGAL & $1,072,787$ & $2,010,000,000$ \\
\hline GUJARAT & 946,086 & $5,870,000,000$ \\
\hline TAMIL NADU & 849,577 & $3,633,944$ \\
\hline ANDHRA PRADESH & 454,729 & $1,430,000,000$ \\
\hline ORISSA & 211,068 & $251,000,000$ \\
\hline MAHARASHTRA & 167,738 & $789,000,000$ \\
\hline PUNJAB & 158,212 & $685,000,000$ \\
\hline KARNATAKA & 152,116 & $482,000,000$ \\
\hline RAJASTHAN & 130,302 & $308,000,000$ \\
\hline JAMMU \& KASHMIR & 121,744 & $381,000,000$ \\
\hline KERALA & 102,390 & $3,470,000,000$ \\
\hline ASSAM & 92,520 & $438,000,000$ \\
\hline MADHYA PRADESH & 64,303 & $119,000,000$ \\
\hline DELHI & 55,184 & $381,000,000$ \\
\hline MANIPUR & 41,004 & $72,800,000$ \\
\hline JHARKHAND & 19,206 & $40,200,000$ \\
\hline HARYANA & 17,818 & $67,500,000$ \\
\hline BIHAR & 16,057 & $65,500,000$ \\
\hline UTTARANCHAL & 11,021 & $18,300,000$ \\
\hline $\begin{array}{l}\text { HIMACHAL } \\
\text { PRADESH }\end{array}$ & 8,752 & $24,000,000$ \\
\hline CHHATTISGARH & 5,191 & $6,007,040$ \\
\hline NAGALAND & 3,656 & $10,500,000$ \\
\hline TRIPURA & 3,167 & $5,433,154$ \\
\hline MEGHALAYA & 2,799 & $17,000,000$ \\
\hline PONDICHERRY & 1,650 & 35,210 \\
\hline DAMAN \& DIU & 643 & 645,869 \\
\hline $\begin{array}{l}\text { ARUNACHAL } \\
\text { PRADESH }\end{array}$ & 418 & $1,332,952$ \\
\hline CHANDIGARH & 363 & $1,722,825$ \\
\hline MIZORAM & 295 & $2,095,701$ \\
\hline SIKKIM & 123 & 631,303 \\
\hline D \& N HAVELI & 34 & 191,896 \\
\hline GOA & 31 & 101,985 \\
\hline A \& N ISLANDS & 3 & \\
\hline TOTAL & $58,62,524$ & $18,862,631,879$ \\
\hline
\end{tabular}

A short dash (-) indicates "not applicable as data is too less/low or the criterion is not applicable" 


\section{Conclusion and Recommendations}

Since the spread, diversity and employment in the unincorporated textile sector has penetrated large swathes of the country and even invisible parts of the economy, it should be strengthened through macro and micro policy framework, which is specific to the state's requirements.

The Vision Strategy \& Action Plan for Indian Textiles \& Apparels formed by the Ministry of Textiles, projects Indian textile and apparel exports to grow from US \$ 39 billion at present to US $\$ 300$ billion by the year 2024-25. This will require additional investment of the order of US $\$ 120$ billion and will result into 35 million additional jobs (Texmin, 2015b).

To accomplish the vision of exports of US\$ 300 billion and $20 \%$ share of global trade by 2024,as stated in the Vision Strategy \& Action Plan for Indian Textiles \& Apparels, India should have a market share of $15 \%$ to $20 \%$ of the global textile and apparel trade from the present $5 \%$ (Texmin, 2015b).

India should also attempt a structural transformation whereby it becomes a net exporter of finished products. This would imply that growth rates in exports of fibre and yarn should start declining and growth rates of apparel, home furnishing, technical textiles and other finished products should grow very rapidly. This would maximise employment generation and value creation within the country and lead to the fulfillment of the Prime Minister's Vision of "Make in India". In the process, investment of about US\$ 180 billion to US\$ 200 billion would take place and about 35 million additional jobs would get created (Texmin, 2015b).

Small capacities of the manufacturing units and more so, low manufacturing efficiencies are a disadvantage, these require urgent change for the better. Technical textiles should also be introduced in other areas. Moreover to make the textile industries in the unincorporated sector more competitive, there is a need to smooth the progress towards rapid growth and modernization of existing firms.

\section{References}

IBEF 2015, India Brand Equity Foundation, Department of Commerce, Ministry of Commerce and Industry, Government of India. www.ibef.org

Makeinindia, 2015, Textile and Garments http://www.makeinindia.com/sector/te xtiles-garments/

Nath, S.K., 2008, National Industrial Classification [All Economic Activities) 2008, Central Statistical Organisation, Ministry of Statistics and Programme Implementation, Government of India, New Delhi, India, Sept, p 42-46, http://fipb.gov.in/attachments/nic_200 8_17apr09.pdf

PIB, 2015a, National Workshop on Integrated Skill Development Scheme held, Press Information Bureau, Government of India, Ministry of Textiles. August $27^{\text {th }} \quad 2015$ http://pib.nic.in/newsite/PrintRelease.a spx?relid=126397

PIB, 2015b, Government formulates policy to promote e-marketing of handloom products.(PIB 21-08-2015) Press Information Bureau, Government of India, Ministry of Textiles, August 21st 2015. http://pib.nic.in/newsite/PrintRelease.a spx?relid $=126254$

PIB, 2015c, Scheme to Promote Geotechnical Textiles in North East, Press Information Bureau, Government of India, Ministry of Textiles. March 24 $4^{\text {th }} 2015$, http://pib.nic.in/newsite/PrintRelease.a spx?relid=117645 
Texmin, 2014, Highlights, Cp 1, Annual Report 2013-2014, Ministry of Textiles, Government of India, http://texmin.nic.in/annualrep/ar_13_1 4_english.pdf

Texmin, 2015a, Reports on Textiles Sector / Industry, http://texmin.nic.in/ ermiu/ stat.htm
Texmin, 2015b, Vision, Strategy and Action Plan for Indian Textile and Apparel Sector, 2015, Ministry of Textiles, http://texmin.nic.in/reports/Vision\%20 Strategy\%20Action\%20Plan\%20for\% 20Indian\%20Textile\%20SectorJuly15. pdf

\section{How to cite this article:}

Meenakshi Sinha Swami and Stanzin Padma. 2016. Extent, Diversity and Potential of Extant Textile Enterprises in India: A Cross State Analysis of the Informal/Unincorporated Economy. Int.J.Curr.Res.Aca.Rev.4(11): 135-141. doi: http://dx.doi.org/10.20546/ijcrar.2016.411.019 